\title{
ARTIKKELIT
}

\section{\I Ikääntyneille suunnatun sosiaalisen markkinoinnin interventioiden taloudellinen arviointi - kartoittava kirjallisuuskatsaus}

\author{
Jussi Partanen ${ }^{1}$, Leena Forma ${ }^{1,2}$, Pekka Rissanen ${ }^{1,2,3}$ \\ ${ }^{1}$ Yhteiskuntatieteiden tiedekunta (terveystieteet), Tampereen yliopisto \\ ${ }^{2}$ Gerontologian tutkimuskeskus (GEREC), Tampereen yliopisto \\ ${ }^{3}$ Terveyden- ja byvinvoinnin laitos (THL)
}

\begin{abstract}
Käyttäytymisen muutokseen tähtääviä kohdennettuja, kansalaisten, ryhmien ja yhteisöjen osallistamista hyödyntäviä menetelmiä on kuvattu lupaaviksi keinoiksi terveyden ja hyvinvoinnin edistämisessä. Tällaisten interventioiden taloudellista arviointia on tehty kuitenkin melko vähän. Taloudellinen arviointitutkimus on systemaattista toimintaa, jossa tunnistetaan, mitataan ja verrattaan vaihtoehtoisten interventioiden kustannuksia ja vaikutuksia. Tähän kirjallisuuskatsaukseen etsittiin tietoa ja tuloksia ikääntyneille suunnatun sosiaalisen markkinoinnin tehokkuudesta. Sosiaalista markkinointia kuvataan käyttäytymisen muutokseen tähtääväksi prosessiksi, jonka alkuperä on kaupallisen markkinoinnin ohella myös sosiaali- ja yhteiskuntatieteissä. Katsauksen aineiston muodostavat yhdeksän kansainvälistä taloudellista arviointitutkimusta, jotka valikoituivat kriteerien mukaan lopulliseen analyysiin. Arvioitujen interventioiden tavoitteet liittyivät ikääntyneiden terveyden edistämiseen ja/tai sairauksien ennaltaehkäisyyn. Katsauksessa arvioitiin myös taloudellisten arviointitutkimusten laatua. Tutkimusten tulosten yhteenvetoa hankaloittavat erot interventioiden tutkimusasetelmissa, arviointinäkökulmissa, vaikuttavuuden mittaustavoissa sekä kansallisiin palvelujärjestelmiin liittyvät erot. Tuloksiin liittyvästä epävarmuudesta huolimatta tutkimusten tulokset viittaavat siihen, että sosiaalista markkinointia hyödyntävät interventiot voivat olla vaikuttavia ja potentiaalisesti myös kustannus-vaikuttavia ikääntyneiden terveyden ja hyvinvoinnin edistämisessä.
\end{abstract}

\section{Johdanto}

Ikääntyvien ihmisten terveys on Euroopassa yleisesti ottaen kohentunut viimeisten vuosikymmenien aikana. Sosioekonomisten ja muidenkin ryhmien väliset koetun terveyden ja hyvinvoinnin erot kuitenkin toistuvat muun muassa empiirisissä tutkimuksissa. (Christensen ym. 2009; Read ym. 2015). Yhtenä keinona saavuttaa parempia ja kestä- 
vämpiä tuloksia terveys- ja hyvinvointierojen kaventamisessa on pidetty kansalaisten ja yhteisöjen osallistamista heidän kohtaamiensa ongelmien määrittelemiseen ja ratkaisukeinojen muotoilemiseen (Israel ym. 1998; Stephens 2007; Wallerstein \& Duran 2006). Terveys- ja hyvinvointierojen kaventamiseen tähtäävät toimet on nähty paitsi arvokkaana yhteiskunnallisena tavoitteena itsessään, myös varautumisena väestön vanhenemiseen (Edwards 2012).

Tämä tutkimus on osa PROMEQ-konsortiota, jonka yhtenä tavoitteena on kansalaislähtöisesti kehittää vaikuttavia keinoja yhteiskunnallisesti heikossa asemassa olevien ryhmien terveyden ja hyvinvoinnin edistämiseksi (http://www.promeq.fi/FI). Konsortiossa kokeillaan sosiaalista markkinointia hyödyntäviä interventioita, joiden vaikuttavuus ja kustannus-vaikuttavuus arvioidaan.

Sosiaalista markkinointia kuvataan käyttäytymisen muutokseen tähtääväksi prosessiksi, jonka alkuperä on kaupallisen markkinoinnin ohella myös yhteiskuntatieteissä (French 2011). Ikääntyneille suunnatun sosiaalisen markkinoinnin vaikuttavuudesta on olemassa jonkin verran tietoa esimerkiksi fyysisen aktiivisuuden lisäämiseen (esim. Fujihira ym. 2015), mielenterveyden (Zanjani ym. 2012) ja terveyden edistämiseen (Mui ym. 2012; Wang ym. 2014) tähtäävistä interventioista. Huolimatta siitä, että sosiaalista markkinointia on kuvattu tehokkaaksi prosessiksi aikaansaada muutoksia ihmisten käyttäytymisessä (esim. Stead ym. 2007), sosiaalisen markkinoinnin taloudellista arviointia on kuitenkin tehty melko vähän (esim. Christopoulos \& Reynolds 2009). Kirjallisuuskatsauksen tavoitteena on yhtäältä kuvata, millaisia tuloksia aiempien taloudellisten arviointitutkimusten perusteella ikääntyneelle väestölle suunnatuista sosiaalista markkinointia hyödyntävistä interventioista on saatu, ja toisaalta arvioida aiemman tutkimuksen laatua. Tutkimuskysymykset ovat:
(1) Millaisista ikääntyneille suunnatuista sosiaalista markkinointia hyödyntävistä interventioista on tehty taloudellista arviointitutkimusta?

(2) Mitä tiedetään aiemman tutkimuksen perusteella tällaisten interventioiden tehokkuudesta?

(3) Miten interventioiden vaikuttavuutta on tutkimuksissa mitattu?

(4) Millaisia vahvuuksia ja heikkouksia arviointitutkimuksissa on?

\section{Sosiaalinen markkinointi}

Sosiaalisen markkinoinnin (social marketing) alkuperä on kaupallisen markkinoinnin periaatteiden soveltamisessa yksilöiden terveyden, elämänlaadun sekä yhteiskunnallisen hyvinvoinnin lisäämiseksi (Kotler \& Zaltman 1971). Sosiaalista markkinointia käsittelevässä kirjallisuudessa sitä kuvataan käyttäytymisen muutokseen tähtääväksi prosessiksi, jonka juuret ovat kaupallisen markkinoinnin ohella myös yhteiskuntatieteellisessä perinteessä (French 2011, 20; French \& Blair-Stevens 2007). Sosiaalinen markkinointi ei ole yhtenäinen teoria, vaan pikemminkin viitekehys, joka sisältää useita teoreettisia aineksia (Stead ym. 2007, 127). Kiinnostus sosiaalista markkinointia kohtaan voidaan yhdistää sosiaali- ja terveyspolitiikan muuttumiseen yksilökeskeisemmäksi, kansalaisia osallistavammaksi ja vastuullistavammaksi (French \& Russell-Bennett 2015, 3; Szmigin ym. 2011). Sosiaalisessa markkinoinnissa hyödynnetään muun muassa käyttäytymistaloustiedettä, sosiaalipsykologiaa, yhteisöjen osallistamista, sosiaalista muotoilua sekä digitaalisen median tarjoamia keinoja (French \& Russell-Bennett, 2015, 3). Yleisimmin sosiaalisen markkinoinnin menetelmiä on sovellettu kansanterveyden edistämiseen. Niin ikään globaalit terveyskysymykset, onnettomuuksien ehkäisy ja ympäristönsuojelu ovat olleet sosiaalisessa markkinoinnissa usein käsiteltyjä aiheita. (Truong 2014, 23.) 
Taulukko 1. Andreasenin (2002) sosiaalisen markkinoinnin pääperiaatteet.

\begin{tabular}{|c|c|}
\hline Kriteeri/pääperiaate & Selitys \\
\hline 1. Käyttäytymisen muutos (Behaviour change) & $\begin{array}{l}\text { Intervention tavoitteena on käyttäytymisen muutos. } \\
\text { Havainnoinnin kohteena olevaa käyttäytymisen } \\
\text { muutosta pyritään mittaamaan. }\end{array}$ \\
\hline $\begin{array}{l}\text { 2. Asiakaslähtöinen tutkimus (Consumer } \\
\text { research) }\end{array}$ & $\begin{array}{l}\text { Interventio perustuu asiakkaiden kokemusten, } \\
\text { arvojen ja tarpeiden ymmärtämiselle, joita on arvioitu, } \\
\text { tunnistettu ja ennalta testattu asiakaslähtöisessä } \\
\text { tutkimustyössä. }\end{array}$ \\
\hline 3. Segmentointi (Segmentation and targeting) & $\begin{array}{l}\text { Interventiot räätälöidään tietyille kohderyhmän } \\
\text { segmenteille. }\end{array}$ \\
\hline 4. "Markkinointimix" (Marketing mix) & $\begin{array}{l}\text { Interventiossa hyödynnetään kohderyhmälle } \\
\text { parhaiten soveltuvaa markkinointimenetelmien } \\
\text { yhdistelmää. Ne pitävät sisällään "tuotteen", "hinnan", } \\
\text { "paikan" sekä "mainostuksen". }\end{array}$ \\
\hline 5. Vaihtokauppa (Exchange) & $\begin{array}{l}\text { Interventio motivoi ja houkuttelee kohdeyleisöä } \\
\text { osallistumaan vapaaehtoisesti interventioon ja tarjoaa } \\
\text { lisäksi jotakin heitä hyödyttävää. }\end{array}$ \\
\hline 6. Kilpailevat tekijät (Competition) & $\begin{array}{l}\text { Interventiossa huomioidaan käyttäytymisen } \\
\text { muutoksen kanssa kilpailevat tekijät ja pyritään } \\
\text { vähentämään tällaisten tekijöiden vaikutusta. }\end{array}$ \\
\hline
\end{tabular}

Taulukko on mukaelma Stead ym. (2007)

Varhaisin ja edelleen laajasti käytetty sosiaalisen markkinoinnin kriteeristö on peräisin Andreasenin (2002) artikkelista, jossa hän esitti kuusi sosiaalista markkinointia kuvaavaa pääperiaatetta. Andreasenin mukaan sosiaalisen markkinoinnin ytimessä on käyttäytymisen muutoksen aikaansaaminen ja sen tulisi perustua markkinoinnin kohdeyleisön tarpeiden ymmärtämiseen (emt., 7). Keskeisin perustelu segmentaatiolle on Andreasenin mukaan sen oletettu tehokkuus verrattuna jonkin tavoitteen yleisluonteisemmin toteutettuun edistämiseen. Lisäksi sosiaalisen markkinoinnin keskeisenä tehtävänä on yhtäältä aikaansaada tavoitellusta käyttäytymisen muutoksesta kohdeyleisön näkökulmasta mahdollisimman houkuttelevaa ja toisaalta minimoida muutoksen kanssa kilpailevia tekijöitä. Andreasenin käyttämät sosiaalisen markkinoinnin kriteerit on koottu taulukkoon 1.

Andreasenin määritelmää ovat sittemmin kehittäneet ja täydentäneet esimerkiksi French ja Blair-Stevens (2007). Heidän mukaansa sosiaalisen markkinoinnin keskiössä ovat asiakaslähtöisyys ja kohderyhmän ymmärtäminen, sillä ne luovat edellytykset käyttäytymismuutosta edistävien ja toisaalta sen kanssa kilpailevien tekijöiden ymmärtämiseksi.

Yksilöiden käyttäytymisen muuttamispyrkimykset eivät kuitenkaan kaikissa tilanteissa ole toimivia, sillä käyttäytymiseen vaikuttavat myös rakenteelliset ja institutionaaliset tekijät (French \& Blair-Stevens 2007; French \& Russell-Bennett 2015; Gordon 2013,114-115). Yksilölliseen muutokseen tähtäävään työhön verrattuna käyttäytymisen muutostavoitetta edistetään kokonaisvaltaisemmin strategisessa sosiaalisessa markkinoinnissa (upstream social marketing), jossa markkinointi suunnataan yksilöiden, ryhmien tai yhteisöjen ohella myös esimerkiksi paikallishallinnon, ammatillisten organisaatioiden tai muun päätöksenteon tasolle (emt., 2013; Truong \& Hall 2013, 115). Etenkin tällä tavoin määriteltynä sosiaalises- 
sa markkinoinnissa on yhtymäkohtia yhteisöllisen muutostyön perinteeseen (vrt. esim. Turunen 2009). Yleisellä tasolla yhteisötyö voidaan määritellä toimintavoiksi, joiden avulla paikalliset tarpeet ja voimavarat tunnistetaan ja valjastetaan myönteisen kehityksen aikaansaamiseksi. Viimeisimpänä yhteisötyön suuntauksena on pidetty kaupallisen toiminnan periaatteiden omaksumista ja hyödyntämistä (emt., 2009).

\section{Taloudellinen arviointi}

Koska kaikkia terveyteen ja hyvinvointiin mahdollisesti myönteisesti vaikuttavia toimenpiteitä ei voida voimavarojen niukkuuden vuoksi ottaa käyttöön (esim. Mooney 2003; Sintonen ym. 1997, 203), käytettävissä olevat voimavarat tulisi kohdentaa siten, että ne tuottaisivat mahdollisimman paljon hyvinvointia. Tämän ajattelun juuret ovat seurausetiikassa, tarkemmin sanottuna utilitarismissa, jonka keskeisenä lähtökohtana on arvioida toimenpiteiden hyväksyttävyys niiden seurausten perusteella.

Taloudellinen arviointitutkimus on systemaattista toimintaa, jossa tunnistetaan, mitataan ja verrattaan vaihtoehtoisten interventioiden kustannuksia ja vaikutuksia (esim. Drummond 2005; Sefton ym. 2004; Sintonen $\&$ Pekurinen 2006). Arvioinnin kohteena voi olla prosessin, suunnitelmien, projektien, ohjelmien tai politiikkojen hyötyjen tai hyödyttömyyden järjestelmällinen tarkastelu. (Konu ym. 2009, 285).

Taloudellisen arviointitutkimuksen keskeiset menetelmät ovat kustannus-vaikuttavuusanalyysi, kustannus-vaikuttavuusanalyysin erityistapauksena pidetty kustannus-utiliteettianalyysi, kustannus-hyötyanalyysi ja kustannusten minimointianalyysi (Sintonen \& Pekurinen 2006, 251). Kaikki arviointimenetelmät mittaavat ja arvottavat kustannuksia rahallisesti, mutta eroavat toisistaan siinä, miten hyötyvaikutukset mitataan ja arvotetaan. Kustannus-vaikuttavuusanalyysissa
(KVA) kahden tai useamman vaihtoehtoisen toimen vaikuttavuutta punnitaan rahamääräisiä kustannuksia vasten. Kustannus-vaikuttavuusanalyysin erityistapauksena pidetty kustannus-utiliteettianalyysi (KUA) eroaa kustannus-vaikuttavuusanalyysista siten, että terveydellisten vaikutusten mittaamisessa otetaan huomioon muutos sekä elämän pituudessa että laadussa. Elämän pituuden ja laadun funktiona määriteltävän laatupainotetun elinvuoden (QALY) muutokset suhteutetaan syntyneisiin kustannuksiin. Kustannushyötyanalyysissa (KHA) sekä toimenpiteen hyödyt sekä kustannukset arvotetaan rahamääräisesti. Kustannusten minimointianalyysissa (KMA) vertailtavien vaihtoehtojen oletetaan olevan vaikuttavuudeltaan yhtäläisiä ja huomiota kiinnitetään ainoastaan kustannusten selvittämiseen ja analysoimiseen. (Emt., 2006.)

Terveystaloustieteessä vaikuttavuus-käsitteellä viitataan yleensä terveyshyötyihin, joiden nähdään olevan oleellisia yleisen hyvinvoinnin kannalta (Konu ym. 2009, 285). Taloudellisen arvioinnin keskeinen ajatus on se, että jotakin toimintoa ei voida asettaa etusijalle yksinomaan sen perusteella, onko se vaikuttavampi tai kustannuksiltaan edullisempi suhteessa johonkin toiseen. Päätöksentekosäännöissä kriteerinä on tavallisesti kustannus-vaikuttavuus, jolloin intervention vaikuttavuutta verrataan sen aiheuttamiin kustannuksiin. (Sefton ym. 2004, 14; Sintonen ym. 2006.) Tavoitteiden saavuttamista arvioitaessa näkökulma on tyypillisesti päätöksentekijän näkökulma - arviointitiedon tarkoituksena on tukea rationaalista päätöksentekoa.

Näkökulma vaikuttaa rajaukseen kustannuksia ja hyötyvaikutuksia arvioitaessa. Taloudelliset arvioinnit tulisi toteuttaa yhteiskunnallisesta näkökulmasta, jolloin otetaan huomioon kaikki vertailtaviin vaihtoehtoihin liittyvä voimavarojen käyttö ja hyötyvaikutukset riippumatta siitä, kenelle ne viime kädessä koituvat (emt., 2006, 252). Usein kuitenkin tyydytään esimerkiksi terveydenhuoltopalvelujen näkö- 
kulmaan, jolloin kustannukset tai mahdolliset säästöt käsittävät vain terveydenhuoltosektorin. Tähän kuitenkin sisältyy vaara, että havaittujen säästöjen sijaan todellisuudessa kustannuksia vain siirretään toimijalta toiselle, eikä kokonaisuuden kannalta säästöjä synny lainkaan. (ns. osa-optimoinnin ongelma; esim. Palmer \& Raftery 1999; ks. myös Byford \& Sefton, 2003.) Vaikuttavuus ja vaikuttavuuden arviointi voidaan määritellä myös monin tavoin kirjoittajan näkökulmasta, tieteellisestä taustasta ja paradigmasta riippuen (Konu ym. 2009,285). Vaikuttavuus-käsitteen käyttöön liittyykin helposti epämääräisyyttä. Lähtökohtana kuitenkin tulisi olla, että vaikuttavuus määritellään aina, kun sitä arvioidaan ja arvioinnin olisi hyvä perustua yleisiin ja tunnustettuihin mittareihin, mikäli tutkittava asia sen mahdollistaa (emt., 2009).

Arviointitutkimukset tarjoavat arvokasta tietoa jonkin toimen arvioimiseksi. Todellisissa resurssien allokointia koskevissa valintatilanteissa tulee huomioida kustannus-vaikuttavuuden ohella kuitenkin myös muita toimen hyväksyttävyyden kannalta olennaisia tekijöitä (Bertram ym. 2016). Vaikuttavuuden arviointiin liitettyjä arvoja ovat sosiaalinen hyvinvointi, elämänlaatu sekä oikeudenmukaisuus. Kysymykset palveluiden tasapuolisesta jakautumisesta ja teknisestä tehokkuudesta ovat niin ikään osa vaikuttavuuden arviointiin liittyvää keskustelua. (Konu ym. 2009, 287.)

\section{Menetelmä ja aineisto}

\section{Kirjallisuushaku}

Tässä tutkimuksessa toteutettiin kartoittava kirjallisuuskatsaus (scoping review) sosiaalisen markkinoinnin taloudellisiin arviointitutkimuksiin. Tällaisissa kirjallisuuskatsauksissa tarkastellaan esimerkiksi aiemman tutkimuksen laajuutta, tehdään arvioita tutkimusalueen soveltuvuudesta systemaattisen katsauksen to- teuttamiseksi, luodaan yhteenvetoa aiemmasta tutkimuksesta sekä tunnistetaan tiedollisia ja tutkimuksellisia aukkoja. Menetelmä soveltuu kehittyville tutkimusaloille, joissa rakennetaan ja vahvistetaan alan tiedollista pohjaa sekä etsitään tutkimukseen perustuvaa näyttöä. (Arksey \& O’Malley 2005; Levac ym. 2010.) Kartoittavissa kirjallisuuskatsauksissa ei tavallisesti arvioida katsaukseen sisällytettyjen tutkimusten laatua (emt., 2010). Tässä tutkimuksessa haluttiin kuitenkin arvioida myös taloudellisten arviointitutkimusten laatua ja tarkastella tutkimusten luotettavuutta.

Hakustrategia esitetään taulukossa 2. Kirjallisuushaussa sosiaalisen markkinoinnin interventioihin viitattiin "social marketing"-termin lisäksi kansainvälisissä sosiaalisen markkinoinnin - kirjallisuuskatsauksissa esiintynein interventioihin viittaavin termein. Tällaiseen toimintatapaan tukeuduttiin, koska taloudellinen arviointi on tuloksia voimakkaasti rajaava tekijä kirjallisuushaussa. Kuviossa 1 kuvataan taloudellisten arviointitutkimusten kirjallisuushaku- ja valintaprosessi. Kriteerit täyttäviä tutkimuksia haettiin Medline-, Cinahl-, Social Services Abstracts- ja Web of Science -tietokannoista. Haku rajattiin englanninkielisiin artikkeleihin. Haku toteutettiin kussakin tietokannassa kokotekstihakuna. Tästä poikkeuksena oli Web of Science -tietokanta, jossa haku toteutettiin aihehakuna kokotekstihaun puuttuessa. Hakusanojen mahdolliset taivutuspäätteet huomioitiin hauissa katkaisumerkillä. Tutkimusten sisäänoton kriteerit olivat:

- Arvioinnin kohteena olevat interventiot oli suunnattu vanhoille tai ikääntyneille ihmisille, jotka eivät olleet laitoshoidossa, eivätkä myöskään olleet vakavasti muistisairaita tai mielenterveysongelmaisia

- Tutkimusten tuli olla taloudellista arviointitutkimusta

- Tutkimuksessa arvioitavien interventioiden tuli olla määriteltävissä sosiaaliseksi markkinoinniksi 
Taulukko 2. Kirjallisuuskatsauksen hakustrategia.

\begin{tabular}{|c|c|}
\hline Hakustrategia: & \\
\hline Hakusanat: & \\
\hline Ikääntyneet ihmiset & - $\quad$ Old \\
\hline & - Elderly \\
\hline & - Geriatric \\
\hline & AND \\
\hline Taloudellinen arviointitutkimus & - Economic evaluation \\
\hline & - $\quad$ Cost-effectiveness \\
\hline & - $\quad$ Cost benefit \\
\hline & - $\quad$ Cost-Utility \\
\hline & AND \\
\hline Sosiaalinen markkinointi & - $\quad$ Social marketing \\
\hline & - Community-based \\
\hline & - Community-integrated \\
\hline & - $\quad$ Participatory \\
\hline & - Social norms intervention \\
\hline & Co-operative \\
\hline & - $\quad$ Behaviour change \\
\hline
\end{tabular}

Kirjallisuuskatsausta varten etsittiin alkuperäistutkimuksia, joissa vanhoille tai ikääntyneille ihmiselle suunnattuja sosiaalista markkinointia hyödyntäviä interventioita tutkittiin taloudellisen arvioinnin menetelmillä. Kirjallisuusviitteistä hylättiin otsikon perusteella ensi vaiheessa lääkehoidolliset, lääketieteelliset interventiotutkimukset ja poistettiin viitteiden kaksoiskappaleet. Luettujen tiivistelmien perusteella hylättiin katsausartikkelit ja arviointitutkimukset, jotka eivät olleet taloudellista arviointia.

Tutkittavina olleiden interventioiden soveltuvuutta tähän katsaukseen arvioitiin soveltaen Andreasen (2002) sosiaalisen markkinoinnin määritelmää. Interventioiden ei tarvinnut täyttää kaikkia määritelmän kuutta kohtaa tullakseen sisällytetyksi tähän tutkimukseen. Keskeisenä pidettiin kuitenkin sitä, että arvioitavan intervention tuli sisältää käyttäytymisen muutostavoite ja olla näin ollen erotettavissa pelkästä tiedotuksesta tai mainonnasta. Soveltuvuutta arvioitaessa pidettiin keskeisenä myös sitä, että interventioiden toteutukses- sa huomioitiin ja osallistettiin niiden kohteena olevia ryhmiä. Kolmanneksi arvioitavan intervention tuli käyttää joitakin markkinointimenetelmiä. Interventioiden soveltuvuutta arvioi pääasiassa yksi tutkija, mutta epäselvät tapaukset ratkaistiin tutkijaryhmän kesken keskustelemalla. Kirjallisuushaun aikana tarkempaa tietoa interventioista haettiin taloudellista arviointia taustoittavista artikkelista, jotka sisälsivät runsaammin kuvailevaa tietoa tutkimuksissa arvioiduista interventiosta. Taustoittavaa kirjallisuutta etsittiin lähinnä tutkittavina olleiden julkaisujen lähdekirjallisuudesta. Haun perusteella löydetyissä tutkimuksissa interventioita ei ollut nimetty sosiaaliseksi markkinoinniksi, eikä käsitettä esiintynyt myöskään sellaisenaan yhdenkään artikkelin kokotekstissä. Kuvailevaa tietoa on hyödynnetty samoin kuitenkin myös aiemmissa sosiaalisen markkinoinnin vaikuttavuutta arvioivissa katsauksissa käyttäytymisen muutokseen tähtäävien interventioiden identifioimiseksi sosiaaliseksi markkinoinniksi (vrt. Carins \& Rundle-Thiele 2014; Kubacki ym 2015; Stead ym. 2007; Truong \& Hall 2013). 


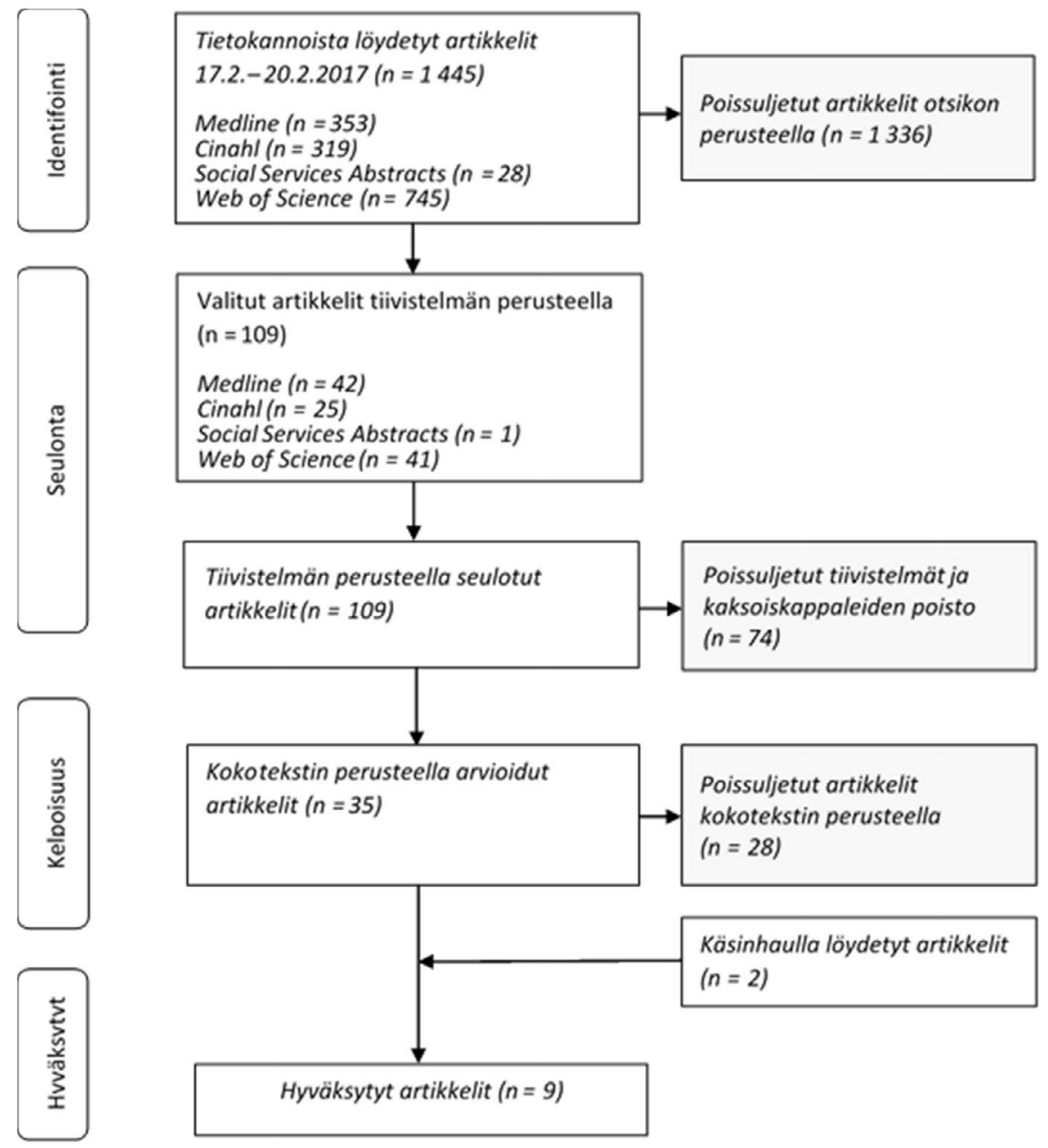

Kuvio 1. Taloudellisten arviointitutkimusten kirjallisuushakuprosessi.

Kirjallisuushaun tuloksena löydettiin seitsemän hakuehdot täyttävää tutkimusta ja yksi tutkimus valikoitui mukaan artikkelien lähdekirjallisuudesta. Lisäksi hakutermien mukainen hakuvahti tuotti yhden tuloksen varsinaisen kirjallisuushaun jälkeen. Hakukriteerit täyttävien tutkimusartikkelien kokonaismäärä oli siten yhdeksän (ks. taulukko 3) ja niissä arvioituja interventioita taustoittavia artikkeleita kaikkiaan kymmenen.

Taloudellisten arviointitutkimusten arvioimisessa sovellettiin Drummondin ym. (2005) taloudellisten arviointitutkimusten laadun arvioimiseksi laatimaa kriteeristöä, jonka avul- la voitiin luoda käsitys tutkimusten tuottaman arviointitiedon laadusta ja luotettavuudesta. Kriteeristöä sovellettiin siten, että mikäli pääkysymystä tarkentavista alakysymyksistä kaikki täyttyivät, katsottiin pääkriteerin täyttyvän.Jos arvioiva tutkimus täytti tarkentavista alakysymyksistä vähintään puolet, tulkittiin pääkriteerin täyttyvän tällöin vain osittain. Kriteerin ei katsottu täyttyvän silloin, jos alakysymyksistä täyttyi vähemmän kuin puolet. Tutkimusten laatua arvioi erillisesti kaksi tutkijaa, ja tutkimuksiin liittyvät eriävät tulokset ratkaistiin keskustelemalla. 


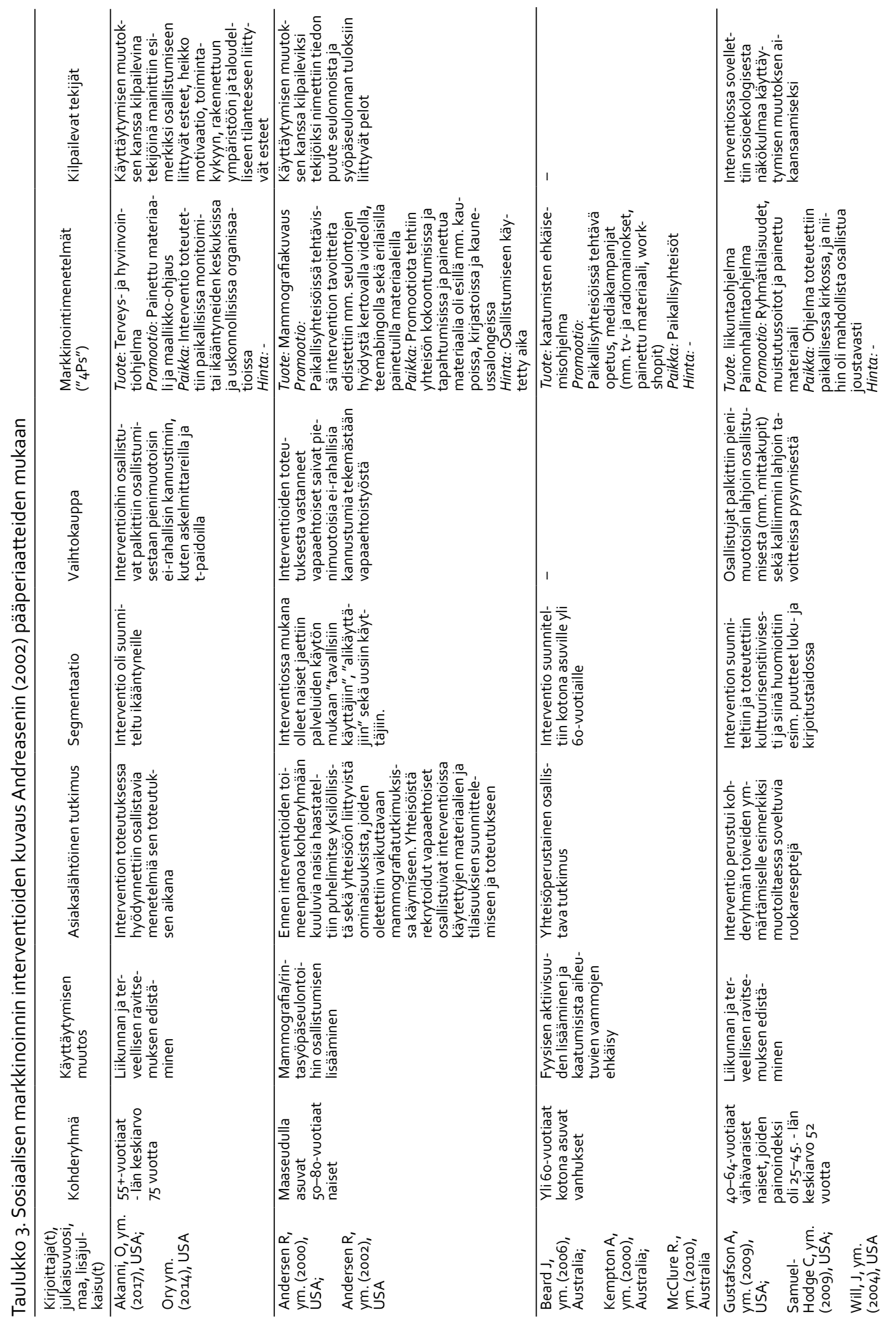




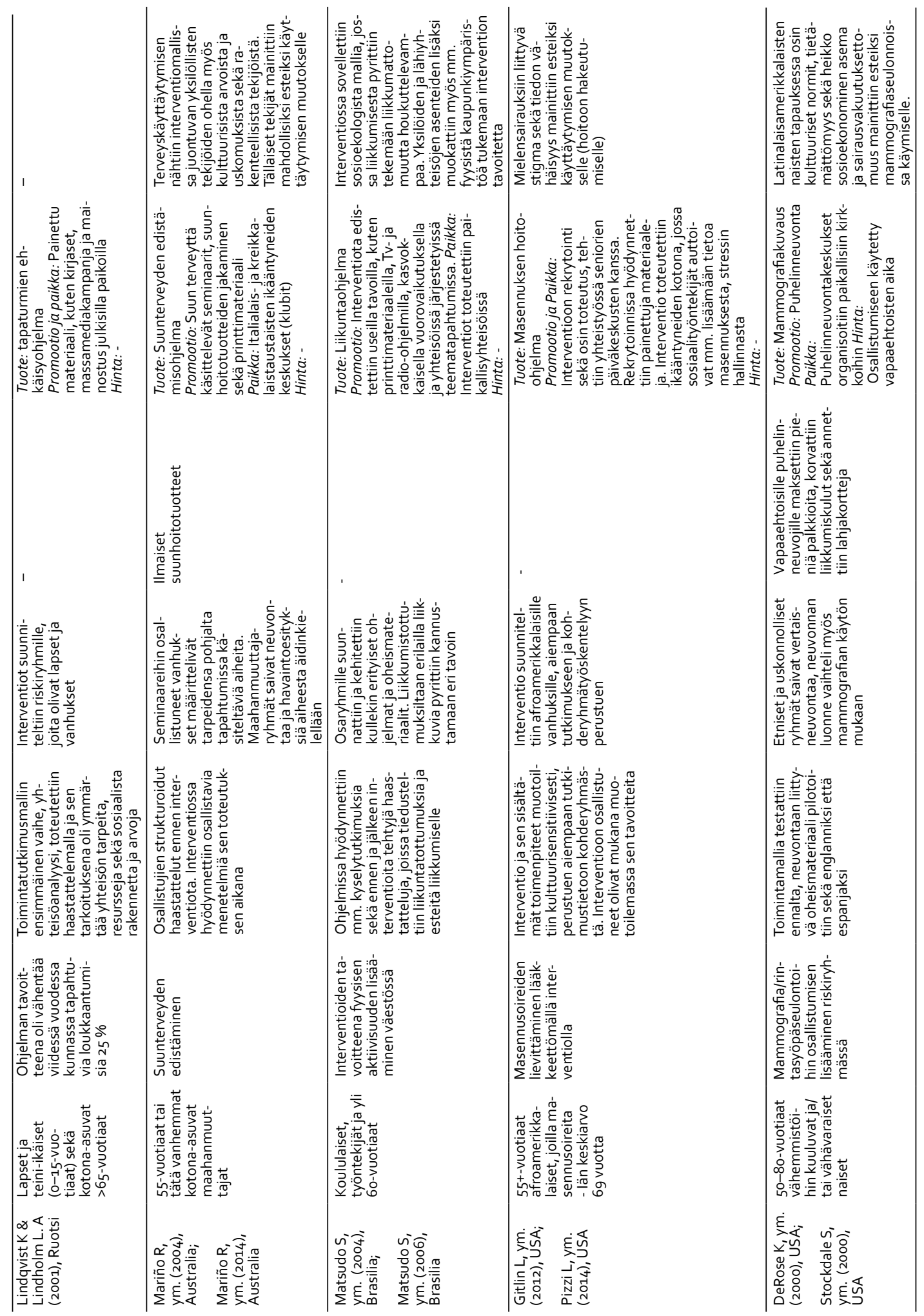




\section{Tulokset}

Katsaukseen valikoitui sisäänottokriteerien perusteella yhdeksän tutkimusta, joissa arvioitiin ikääntyneille suunnattuja sosiaalisen markkinoinnin menetelmiä hyödyntäviä interventioita. Katsaukseen valikoituneista yhdeksästä tutkimuksesta viisi oli yhdysvaltalaisia, kaksi australialaisia, yksi tutkimus ruotsalainen ja yksi brasilialainen. Tutkimukset on julkaistu vuosina 2000-2017. Kuvaileva tieto interventioista on koottu Andreasen (2002) sosiaalisen markkinoinnin kriteerien mukaisesti taulukkoon 3.

Interventioiden tavoitteina oli terveyteen liittyvän elämänlaadun edistäminen $\mathrm{ja} /$ tai sairauksien sekä tapaturmien ennaltaehkäisy. Tutkittavina olivat usein etnisen (Pizzi ym. 2014; Stockdale ym. 2000), maahanmuuttajataustan (Mariño ym. 2014), tai vähävaraisuuden vuoksi (Andersen ym. 2002; Gustafson ym. 2009) vähemmistöryhmiin kuuluvat ihmiset. Tutkimusten kohdejoukoista nuorin oli 40-64-vuotiaat naiset (Gustafson ym. 2009). Muiden tutkimusten interventiot oli suunnattu tätä vanhemmille ikäryhmille. Kahdessa tutkimuksessa kohderyhmänä olivat 50-80-vuotiaat naiset (Andersen ym. 2002; Stockdale ym. 2000). Kolme interventioista oli suunnattu 55-vuotiaille tai tätä vanhemmille (Akanni ym. 2017; Mariño ym. 2014; Pizzi ym. 2014) ja kolmen intervention kohderyhmänä olivat 60-vuotiaat tai tätä vanhemmat (Beard ym. 2006; Lindqvist \& Lindholm 2001; Matsudo ym. 2006). Kahdessa arvioitavassa interventiossa oli mukana ikääntyneiden lisäksi myös muita kohderyhmiä. Näitä olivat ruotsalaisessa kunnassa toteutettua loukkaantumistapaturmien ehkäisemiseksi suunniteltua interventiota arvioiva tutkimus (Lindqvist \& Lindholm 2001) sekä São Paulossa fyysisen aktiivisuuden lisäämiseksi toteutettuja interventioita arvioiva tutkimus (Matsudo ym. 2006).
Ikääntyneille suunnattujen sosiaalisen markkinoinnin interventioiden kuvailu

Kaikkien tutkimuksissa kuvattujen interventioiden tavoitteena oli käyttäytymisen muutos, ja ne hyödynsivät kohderyhmälähtöisiä tai osallistavia menetelmiä. Tämä tarkoitti enimmäkseen kohderyhmien haastattelua ennen interventioiden toimeenpanoa sekä kohderyhmän osallistamista interventioiden toteutuksen aikana. Viiden intervention tavoitteena oli fyysisen toimintakyvyn ylläpitäminen, vahvistaminen tai kaatumistapaturmien ehkäisy (Akanni ym. 2017; Beard ym. 2006; Gustafson ym. 2009; Lindqvist \& Lindholm 2001; Matsudo ym. 2006). Kahden intervention tavoitteena oli mammografiakuvauksissa käymisen edistäminen (Andersen ym. 2002; Stockdale ym. 2000). Lisäksi yksi tutkimus arvioi suunterveyden parantamiseksi (Mariño ym. 2014) ja yksi masennusoireiden hoitamiseksi (Pizzi ym. 2014) kehitettyjä interventioita.

Kaikki interventiot toteuttivat segmentaatiota jollakin tasolla ja ne erosivat näin luonteeltaan yleisemmin ja kohdentumattomammin toteutetusta terveyden edistämiseen tähtäävästä toiminnasta. Segmentaatiota saatettiin toteuttaa ikäryhmittäisen jaottelun lisäksi muiden tekijöiden, kuten esimerkiksi etnisen taustan perusteella. Kaikkein pisimmälle segmentointi oli viety mammografiakuvantamispalvelujen käytön lisäämiseen tähtäävissä interventioissa, joissa kohdeyleisöön kuuluvat naiset jaettiin käyttäjäryhmiin aiemman palvelun käytön mukaan ja interventiossa annettava neuvonta vaihteli luonteeltaan käyttäjäryhmittäin (Andersen ym. 2002, Stockdale ym. 2000.

Tässä tutkimuksessa Andreasenin (2002) tarkoittama vaihtokauppa määriteltiin mahdollisimman konkreettiseksi aineelliseksi hyödyksi, jota osallistujat saivat interventioihin osallistumisesta. Konkreettista vaihto oli viidessä interventiossa. Kahdessa tutkimuksessa vertaisryhmään kuuluvat vapaaehtoiset saivat osallistumisesta pienen rahallisen tai ei-rahallisen palkkion. (Andersen ym. 2002; Stockdale 
ym. 2000). Kolmessa hankkeessa osallistumista ja käyttäytymismuutostavoitteita tuettiin lahjoittamalla osallistujille pienimuotoisia kannustimia, kuten ilmaisia suunhoitotuotteita (Mariño, ym. 2014) tai fyysisen aktiivisuuden ja painonhallinnan tueksi tarkoitettuja tuotteita (Akanni ym. 2017; Gustafson ym. 2009).

Kahta interventiota lukuun ottamatta tavoitellun käyttäytymismuutoksen kanssa kilpaileviin tekijöihin kiinnitettiin huomiota, ja niiden vaikutusta pyrittiin vähentämään. Käyttäytymisen muutoksen kanssa kilpailevat esteet liitettiin esimerkiksi sosiokulttuurisesti omaksuttuihin ja ylläpidettyihin toimintatapoihin (Andersen ym. 2002; Mariño ym.. 2014; Matsudo ym. 2006; Stockdale ym. 2000) tai sosiaaliseen stigmaan (Pizzi ym. 2014).

Markkinointimenetelmiä hyödynnettiin jossain määrin kaikissa interventioissa. Useimmissa hyödynnettiin painetun materiaalin käyttöä, mutta tavoitteitta edistettiin myös esimerkiksi ryhmätilaisuuksissa tai yksilöllisen vuorovaikutuksen keinoin. Useimmissa interventiossa paikallisyhteisöillä oli keskeinen rooli tutkittavien rekrytoimisessa ja ne toteutettiin kohderyhmän näkökulmasta merkityksellisissä ja sijainniltaan läheisissä paikoissa, kuten osana päiväkeskusten tai paikallisten kirkkojen toimintaa.

Kahdessa tutkimuksessa pyrittiin vaikuttamaan myös institutionaalisiin ja rakenteellisiin tekijöihin, joten niihin sisältyi strategisen sosiaalisen markkinoinnin piirteitä. Interventioissa tavoiteltiin esimerkiksi rakennetun ympäristön muokkaamista turvallisemmaksi (Beard ym. 2006; Gustafson ym. 2009; Lindqvist \& Lindholm 2001) tai liikkumiseen houkuttelevammaksi (Matsudo ym. 2006).

\section{Interventioiden taloudellinen arviointi}

Tämän tutkimuksen aineiston yhdeksästä tutkimuksesta kolmessa analyysimenetelmänä oli kustannus-vaikuttavuusanalyysi, kolmessa kustannus-utiliteettianalyysi ja kahdessa käytetty arviointimenetelmä oli nimetty kus- tannus-hyötyanalyysiksi (Beard ym. 2006; Lindqvist \& Lindholm 2001). Yksi tutkimuksista oli kustannusten minimointianalyysi.

Kuvaus tutkimusten soveltamista menetelmistä, hyötyvaikutuksista, arvioinnin näkökulmista ja päätuloksista on esitetty Taulukossa 4 . Taloudelliset arviointitutkimukset on ryhmitelty niissä käytetyn analyysityypin mukaisesti.

\section{Kustannusten arvioinnin näkökulma}

Taloudelliset arvioinnit nimittivät kustannusten arvioinnin näkökulmaansa yhteiskunnalliseksi (societal/social perspective) (Akanni 2017; Andersen 2002; Beard 2006; Matsudo ym. 2006; Lindqvist \& Lindholm 2001; Mariño ym. 2014; Pizzi ym. 2014; Stockdale 2000) yhtä arviointitutkimusta lukuun ottamatta, jossa kustannuksia arvioitiin suppeammin ohjelman tuottajan näkökulmasta (Gustafson ym. 2009). Ohjelmien toimeenpanoon käytettyjen suorien voimavarojen, kuten henkilöstövoimavarojen, tarvikkeiden, osallistumista tukevien kannustimien ja tilojen vuokraamisesta syntyneiden kulujen lisäksi, useimmat kustannusvaikuttavuus- ja kustannus-utiliteettianalyyseista pyrkivät arvottamaan vapaaehtoistyön käyttöön liittyneitä kustannuksia, joita arvioitiin vaihtoehtoiskustannusten kautta. (Akanni 2017; Andersen 2002; Matsudo ym. 2006; Stockdale 2000). Vapaaehtoistyön arvotusperusteena käytettiin useimmiten vastaavanlaisista työtehtävistä maksettavia palkkoja. Palvelujärjestelmän näkökulmasta tehdyssä yksittäisessä kustannus-utiliteettianalyysissa huomioitiin kustannuksina myös lääkekuluja ja sosiaali- ja terveyspalvelujen käytöstä aiheutuneita kustannuksia (Pizzi ym. 2014). Aineiston kustannukset-säästöt-analyyseista toisessa pyrittiin arvottamaan myös tuottavuuskustannuksia (Lindqvist \& Lindholm 2001).

\section{Vaikuttavuusmittarit}

Kahdessa tutkimuksessa vaikuttavuutta mitattiin aikuisväestön terveyteen liittyvää elämänlaatua mittaavilla mittareilla (Akanni ym. 2017; Pizzi ym. 2014). Molemmissa tutkimuksissa 


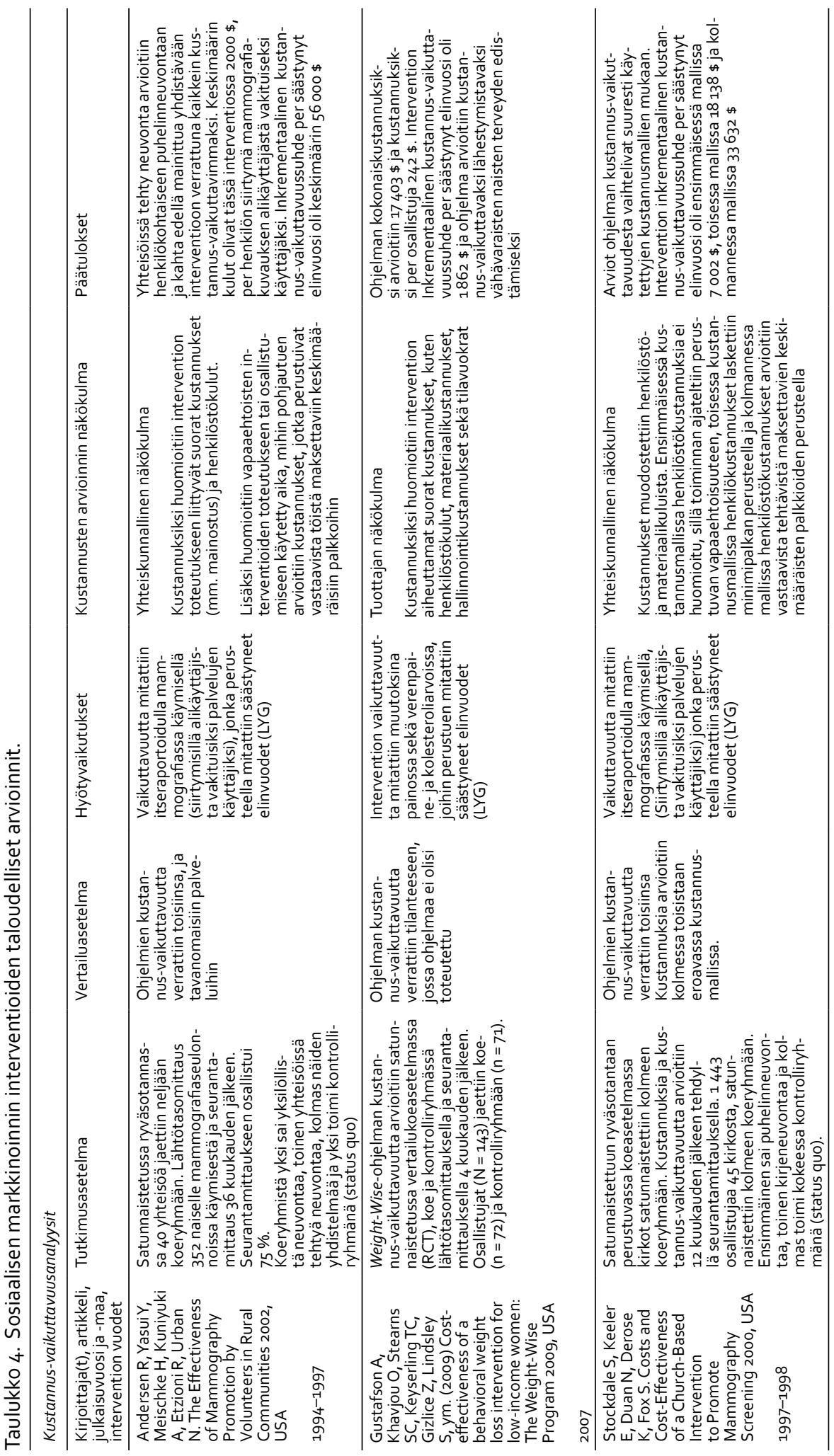




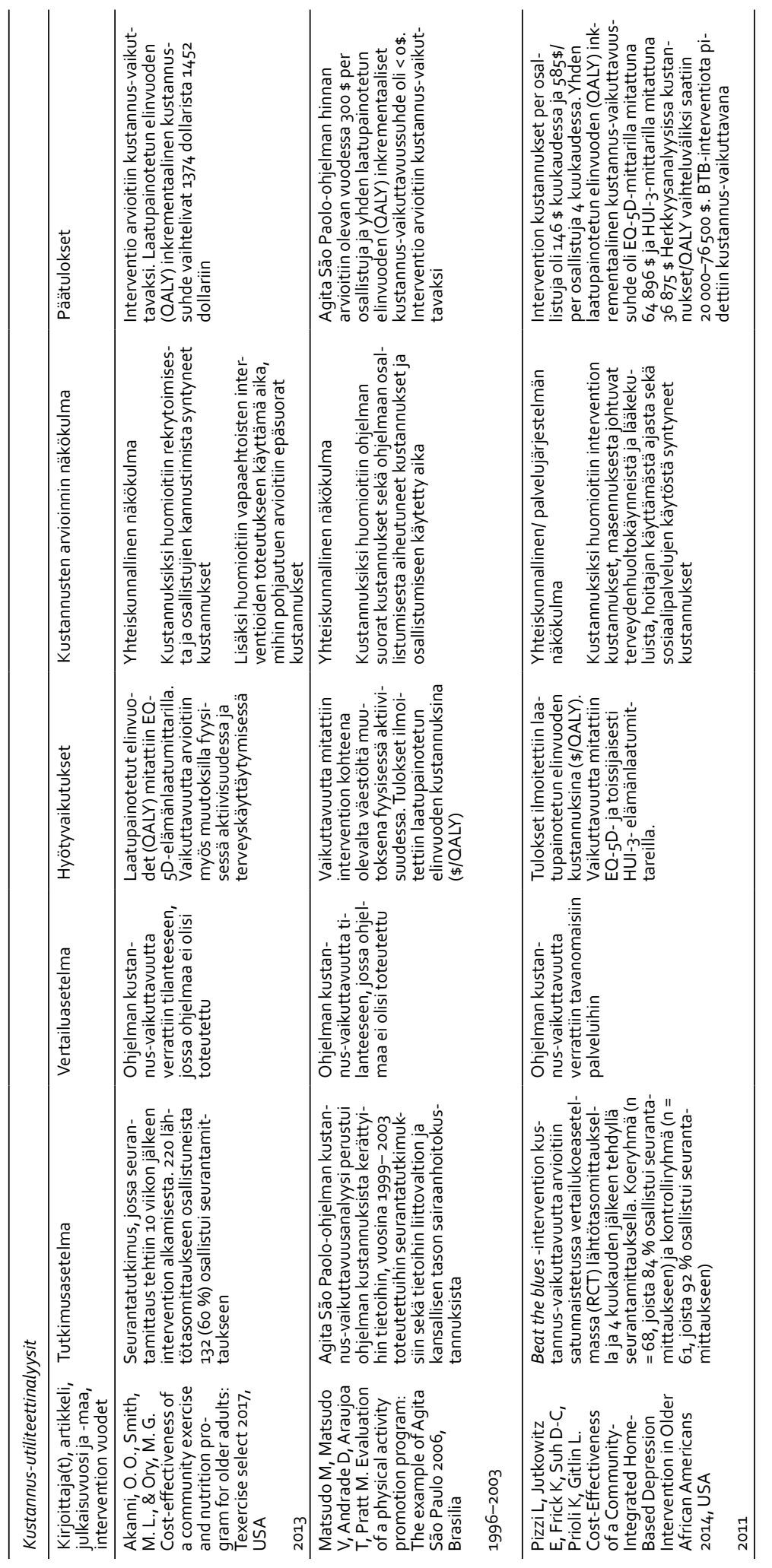




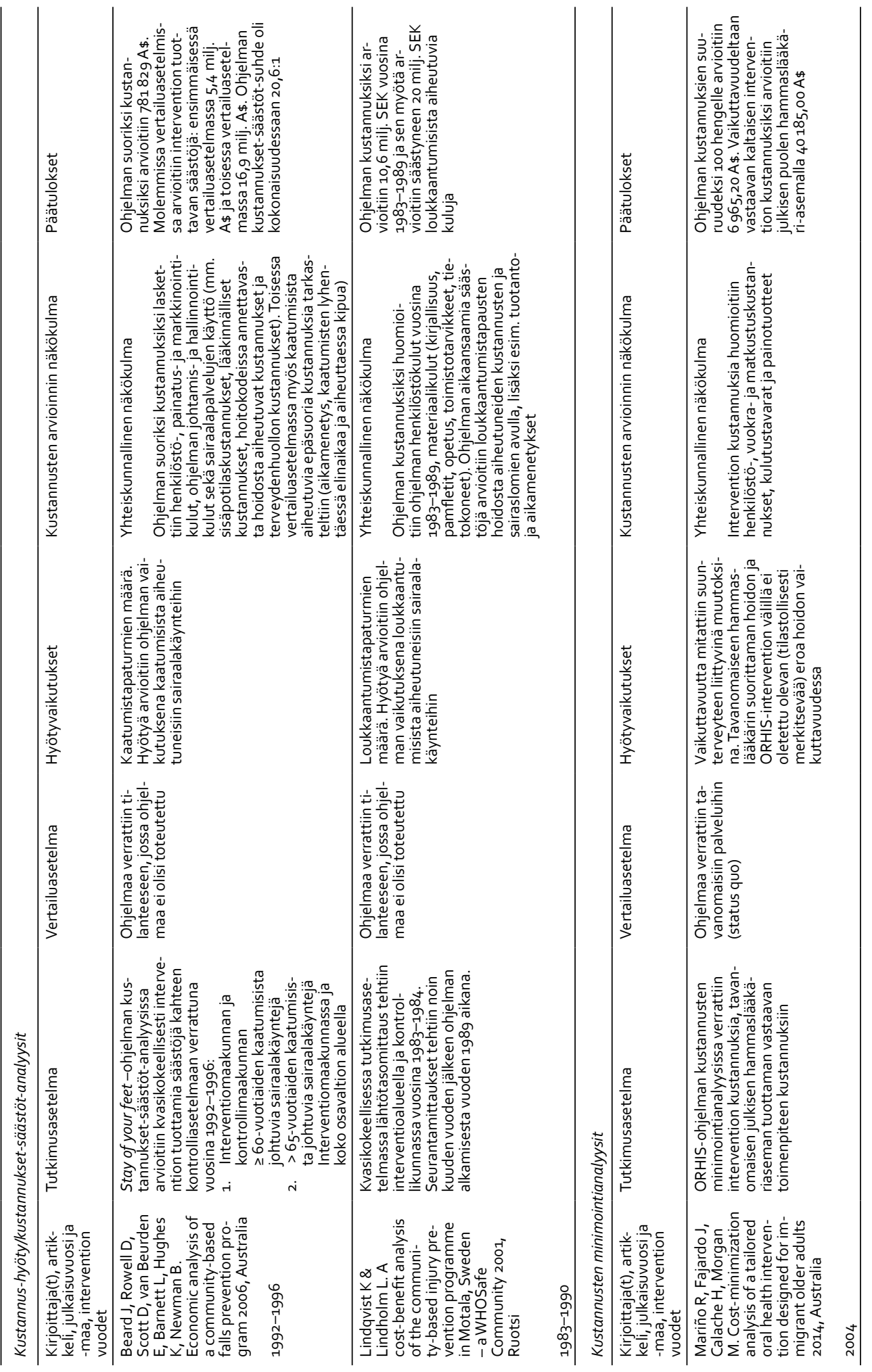


käytettiin ensisijaisena vaikuttavuusmittarina EQ-5D-mittaria. Masennuksen hoito-ohjelman vaikuttavuutta arvioitiin lisäksi toissijaisesti myös HUI-3-mittarilla (Pizzi ym. 2014). Muissa tutkimuksissa vaikuttavuutta mitattiin jollakin terveydentilaan yhteydessä olevalla välimuuttujalla, kuten halutun käyttäytymistavoitteen aikaansaamisena (Andersen ym. 2002; Matsudo ym. 2004; Stockdale ym. 2000) tai muutoksina painoindeksissä sekä verenpaine- ja kolesteroliarvoissa (Gustafson ym. 2009).

\section{Kustannus-vaikuttavuusanalyysit}

Andersen ym. (2002) vertailivat mammografiakuvausten edistämiseen tähtäävien interventioiden kustannus-vaikuttavuutta satunnaistettuun ryväsotantaan perustuvalla 352 osallistujan suuruisella aineistolla. Interventiot toteutettiin maaseutumaisilla alueilla. Tutkimuksessa tarkasteltiin kolmen neuvontatavan vaikuttavuutta ja kustannus-vaikuttavuutta verrattuna kontrolliryhmään, johon kuuluvat eivät osallistuneet edistämisohjelmiin. Vaikuttavuutta mitattiin itseraportoidulla mammografiakuvantamispalveluiden käytöllä kolmen vuoden jälkeen lähtötasomittauksesta, johon osallistui 75 prosenttia lähtötasomittaukseen osallistuneista. Yhteisöissä annettu vertaisneuvonta arvioitiin henkilökohtaiseen puhelinneuvontaan ja näiden yhdistelmään verrattuna kaikkein kustannus-vaikuttavimmaksi. Intervention inkrementaalinen kustannus-vaikuttavuussuhde säästynyttä elinvuotta (LYG) kohti oli 56000 Yhdysvaltain dollaria.

Stockdale ym. (2000) vertasivat mammografiakuvantamisen eri tavoin toteutettujen edistämisohjelmien kustannus-vaikuttavuutta tavanomaisiin palveluihin verrattuna satunnaistettuun ryväsotantaan perustuvalla aineistolla. Lopullisessa kustannus-vaikuttavuusanalyysissa ei kuitenkaan huomioitu kirjeitse toteutettua interventiota, koska sen vaikuttavuus ei eronnut kontrolliryhmästä tilastollisesti merkitsevästi. Interventioiden vaikuttavuutta arvioitiin itseraportoidulla mammografiakuvantamispalveluiden käytöllä vuoden jälkeen lähtötasomittauksesta. Puhelimitse toteutetun vertaisneuvonnan intervention inkrementaalinen kustannus-vaikuttavuussuhde säästynyttä elinvuotta (LYG) kohti vaihteli tavanomaiseen neuvontaan verrattuna 7002 Yhdysvaltain dollarista 33362 dollariin, riippuen vapaaehtoisten työpanoksen rahamääräisestä arvottamisesta.

Gustafson ym. (2009) arvioivat vähävaraisille naisille suunnatun fyysisen aktiivisuuden lisäämiseen ja painonhallintaan tähtäävän ohjelman kustannus-vaikuttavuutta satunnaistella kokeella, jossa koeryhmään kuuluvat $(\mathrm{n}=72)$ osallistuivat ohjelmaan ja vertailtavaan "odotuslistaan" kuuluville ( $\mathrm{n}=71$ ) tarjottiin palvelu myöhemmin. 16-viikkoisen ohjelman aikana järjestetyissä, kahden tunnin mittaisissa, viikoittaisissa ryhmätilaisuuksissa käsiteltiin terveelliseen ruokavalioon ja liikuntaan liittyviä aiheita. Intervention vaikuttavuutta mitattiin ensisijaisesti muutoksina painossa neljän kuukauden jälkeen toteutetussa seurantamittauksessa. Koeryhmään kuuluvat laihtuivat keskimäärin 4,4 kilogrammaa intervention aikana ja systolinen verenpaine aleni $6.2 \mathrm{mmHg}$ odotuslistaan kuuluviin verrattuna. Intervention inkrementaalinen kustannus-vaikuttavuussuhde säästynyttä elinvuotta (LYG) kohti oli 1862 Yhdysvaltain dollaria. Tulos arvioitiin kustannus-vaikuttavaksi.

\section{Kustannus-utiliteettianalyysit}

Akanni ym. (2017) arvioivat liikunta- ja ravitsemusohjelman kustannus-utiliteettia seurantatutkimuksessa ennen ja jälkeen interventiota. Ohjelman tavoitteena oli lisätä osallistujien tietoa fyysisen aktiivisuuden ja ravitsemuksen hyödyistä, vahvistaa heidän kykyään tehdä parempia terveystapoihin liittyviä valintoja, ylläpitää fyysistä toimintakykyä, kuten istumista, seisomista, kävelemistä ja tarjota keinoja ehkäistä kaatumisia. Ohjelman kesto oli kaikkiaan 12 viikkoa, joista kaksi viikkoa käytettiin ohjelmaan rekrytoimiseen ja kymmenen viikkoa opetustilaisuuksien pitämiseen. Kymmenen viikon aikana pidettiin kaikkiaan 
20 työpajatilaisuutta, joiden kesto oli kerrallaan 1,5 tuntia. Seurantamittaukseen osallistui 60 prosenttia osallistujista. Laatupainotetut elinvuodet laskettiin EQ-5D-elämänlaatumittarin perusteella. EQ-5D-arvo lähtötasomittauksessa oli 0,75 ja seurantamittauksessa 0,77 ( $<<0,1)$. Laatupainotetun elinvuoden (QALY) inkrementaaliset kustannukset verrattuna tilanteeseen ennen interventiota vaihtelivat välillä 1374-1452 Yhdysvaltain dollaria ja interventio arvioitiin kustannus-vaikuttavaksi.

Matsudo ym. (2006) tutkivat fyysisen aktiivisuuden lisäämiseen tähtäävien interventioiden kustannus-vaikuttavuutta hankkeessa, jossa vaikuttavuutta arvioitiin muutoksina väestön fyysisessä aktiivisuudessa neljän vuoden aikana. Interventioiden tavoitteena oli päivittäisen liikkumiseen käytetyn ajan lisääminen 30 minuuttiin. Interventioiden kustannuksiin laskettiin ohjelman suorat ja epäsuorat kustannukset sekä aikakustannukset osallistuneille. Yhden laatupainotetun elinvuoden (QALY) inkrementaaliset kustannukset olivat vähemmän kuin nolla Yhdysvaltain dollaria. Ohjelma arvioitiin kustannus-vaikuttavaksi.

Pizzi ym. (2014) arvioivat afroamerikkalaisille ikääntyneille suunnatun lääkkeettömän masennuksen hoito-ohjelman kustannus-vaikuttavuutta satunnaistetussa kokeessa, jossa koeryhmä osallistui ohjelmaan ja kontrolliryhmään kuuluvat saivat tavanomaiset palvelut. Tutkimukseen osallistuneet kävivät läpi kaksi perättäistä seulontaa masennusoireiden tunnistamiseksi kahden viikon aikana. Seulonnassa hyödynnettiin koettua terveydentilaa mittaavaa PHQ-9-kyselyä. Tutkimukseen osallistuneet satunnaistettiin koeryhmään ja vertailtavaan"odotuslistaan", johon kuuluville tarjottiin interventio neljän kuukauden jälkeen. Neljän kuukauden mittainen ohjelma koostui enintään 10 tilaisuudesta,joissa sosiaalityöntekijät järjestivät osallistujille muun muassa palveluohjausta ja opettivat stressinhallintatekniikoita, joiden avulla tuettiin osallistujien itse määrittelemien tavoitteiden saavuttamista. Ohjelman vaikuttavuutta arvioitiin kahdella elämänlaatumittarilla. Seurantamittaukseen osallistui 88 prosenttia osallistujista. Lähtötasomittauksessa koeryhmän EQ-5D-tuloksen keskiarvo oli 0,566, mikä oli hieman alhaisempi kuin odotuslista-verrokeilla $(0,582)$. Neljän kuukauden jälkeen toteutetussa seurantamittauksessa koeryhmän EQ-5D-tulos oli 0,665 ja odotuslistaverrokeilla 0,635. HUI-3-mittarilla arvioituna koeryhmän tulos oli lähtötasomittauksessa 0,335 ja seurantamittauksessa 0,479. Kontrolliryhmän vastaavat mittaustulokset olivat 0,432 ja 0,496.Yhden laatupainotetun elinvuoden (QALY) inkrementaaliset kustannukset olivat EQ-5D-mittarilla mitattuna 64896 dollaria ja HUI-3-mittarilla 36875 dollaria. Herkkyysanalyysissa laatupainotetun elinvuoden kustannusten vaihteluväliksi saatiin 20000-76500 Yhdysvaltain dollaria, mihin perustuen interventio arvioitiin kustannus-vaikuttavaksi.

\section{Kustannus-hyöty/kustannus-säästöanalyysit}

Beard ym. (2006) arvioivat kaatumistapaturmien ehkäisyyn suunnitellun ohjelman kustannuksia ja säästöjä kahdella kvasikokeellisella asetelmalla, jossa ohjelman säästöjä arvioitiin kontrollimaakuntaan sekä koko osavaltioon verrattuna neljän vuoden ajalta. Ensimmäisessä vertailuasetelmassa sairaalakäynneistä syntyneitä kustannuksia verrattiin interventiomaakunnan ja väestörakenteeltaan samankaltaisen kontrollimaakunnan välillä, jossa ohjelmaa ei toteutettu. Toisessa vertailuasetelmassa sairaalakäynneistä syntyneitä kustannuksia verrattiin kaatumistapaturmiin yhdistettävien diagnoosien (DRG) mukaan interventiomaakunnassa ja koko osavaltiossa. DRG-luokitusten kautta laskettiin myös kaatumisista syntyneet epäsuorat kustannukset. Ensimmäisessä koeasetelmassa intervention säästöiksi arvioitiin 5,4 miljoonaa Australian dollaria. Toisessa vertailuasetelmassa epäsuorien kustannusten ollessa mukana intervention tuottamat säästöt olivat 16,9 miljoonaa Australian dollaria suuremmat kuin sen kustannukset. 
Lindqvist \& Lindholm (2001) arvioivat kvasikokeellisessa tutkimusasetelmassa tapaturmien ehkäisemiseksi suunnitellun ohjelman kustannuksia ja säästöjä, joita arvioitiin muutoksina loukkaantumistapaturmista ja sairaslomista aiheutuneissa kustannuksissa. Tapaturmien vähenemisen arvioitiin säästäneen 20 miljoonaa Ruotsin kruunua ohjelman elinkaaren aikana.

\section{Kustannusten minimointianalyysi}

Mariño ym. (2014) tekemässä kustannusten minimointianalyysissa suunterveyden ylläpitämiseen tarkoitetun intervention kustannuksia verrattiin julkisen hammaslääkäriaseman tuottamien vastaavanlaisten toimenpiteiden kustannuksiin (care as usual). Ohjelman ja vastaavanlaisen toimenpiteiden vaikuttavuuden oletettiin olevan sama (ts. ero ei tilastollisesti merkitsevä). Kustannuksiin laskettiin henkilöstö-, vuokra- ja matkustuskustannukset, suunhoitotuotteet ja painettu materiaali. Ohjelmaan kuuluneiden sadan henkilön kustannukset olivat 6965 Australian dollaria, kun taas vastaavanlaisten palvelujen tuottamisen kustannukset olivat 40165 Australian dollaria. Ohjelman mukaisen toiminnan arvioitiin olevan voimavarojen tehokasta käyttöä tavanomaiseen toimintaan verrattuna.

\section{Taloudellisten arviointitutkimusten laadun arviointi}

Taloudellisten arviointitutkimusten laadun arviointi on esitetty taulukossa 5 . Katsauksen aineiston muodostavien taloudellisten arviointitutkimusten joukossa on hyviä, metodisesti vahvoja taloudellisia arviointeja, mutta myös tutkimuksia, joissa on selviä puutteita. Tutkimusten puutteet liittyivät yleisimmin kustannusten ja vaikutusten ajalliseen mukauttamiseen (diskonttaamiseen) (taulukko 5), missä ilmeni puutteita kuudessa tutkimuksessa. Neljässä tutkimuksessa kustannuksiin ja vaikutuksiin liittyvää epävarmuutta ei oltu analysoitu tai raportoitu. Joissakin tutkimuksissa toimen- pidevaihtoehdot tai arvioinnin näkökulma oli kuvattu epäselvästi. Yksittäisessä tutkimuksessa (Matsudo ym. 2006) ilmeni selviä puutteita myös ohjelmien kustannusten ja vaikuttavuuden esittämisessä. Aineiston kustannus-hyötyanalyyseiksi nimettyjen arviointitutkimusten tapauksessa oikeampi nimitys olisi "kustannukset-säästöt -analyysi" (cost-offset, cost-savings), sillä edellä mainituissa tutkimuksissa tarkastellaan säästöjä. Kustannus-hyötyanalyysi edellyttäisi, että hyötyvaikutukset olisi arvotettu rahamääräiseksi tätä tarkoitusta varten suunnitelluilla menetelmillä. Katsauksen kartoittavan luonteen takia kustannukset-säästöt -analyysit päädyttiin kuitenkin sisällyttämään katsaukseen. Lisäksi tutkimuksissa käytetyt arviointiasetelmat vaihtelivat ja tutkimuksiin osallistuneiden määrä oli tyypillisesti kokeellisissa tutkimusasetelmissa melko pieni. Tutkimusten seuranta-ajat olivat myös tyypillisesti lyhyitä, useimmiten alle kuusi kuukautta ja pisimmillään noin vuoden mittaisia. Poikkeuksen muodosti Andersen ym. (2002) tutkimus, jossa seurantamittaus tehtiin noin kolmen vuoden jälkeen lähtötasomittauksesta. Myös aineiston kustannukset-säästöt-analyyseissa (Beard ym. 2006 ja Lindqvist \& Lindholm 2001) ohjelmien säästöjä arvioitiin usean vuoden ajalta.

\section{Pohdinta}

Tähän kartoittavaan kirjallisuuskatsaukseen etsittiin tietoa sekä tuloksia ikääntyneille suunnattujen sosiaalisen markkinoinnin interventioiden taloudellisesta arviointitutkimuksesta, ja arvioitiin lisäksi aiemman tutkimuksen laatua ja luotettavuutta. Kirjallisuushaku tehtiin Medline-, Cinahl-, Social Services Abstracts- ja Web of Science -tietokannoista. Sisäänottokriteerejä hyödyntämällä katsauksen aineistoksi saatiin yhdeksän taloudellista arviointitutkimusta. Katsauksessa käsiteltyjen sosiaalista markkinointia hyödyntävien interventioiden tavoitteet liittyivät terveydenedistämiseen ja sairauksien sekä tapaturmien en- 


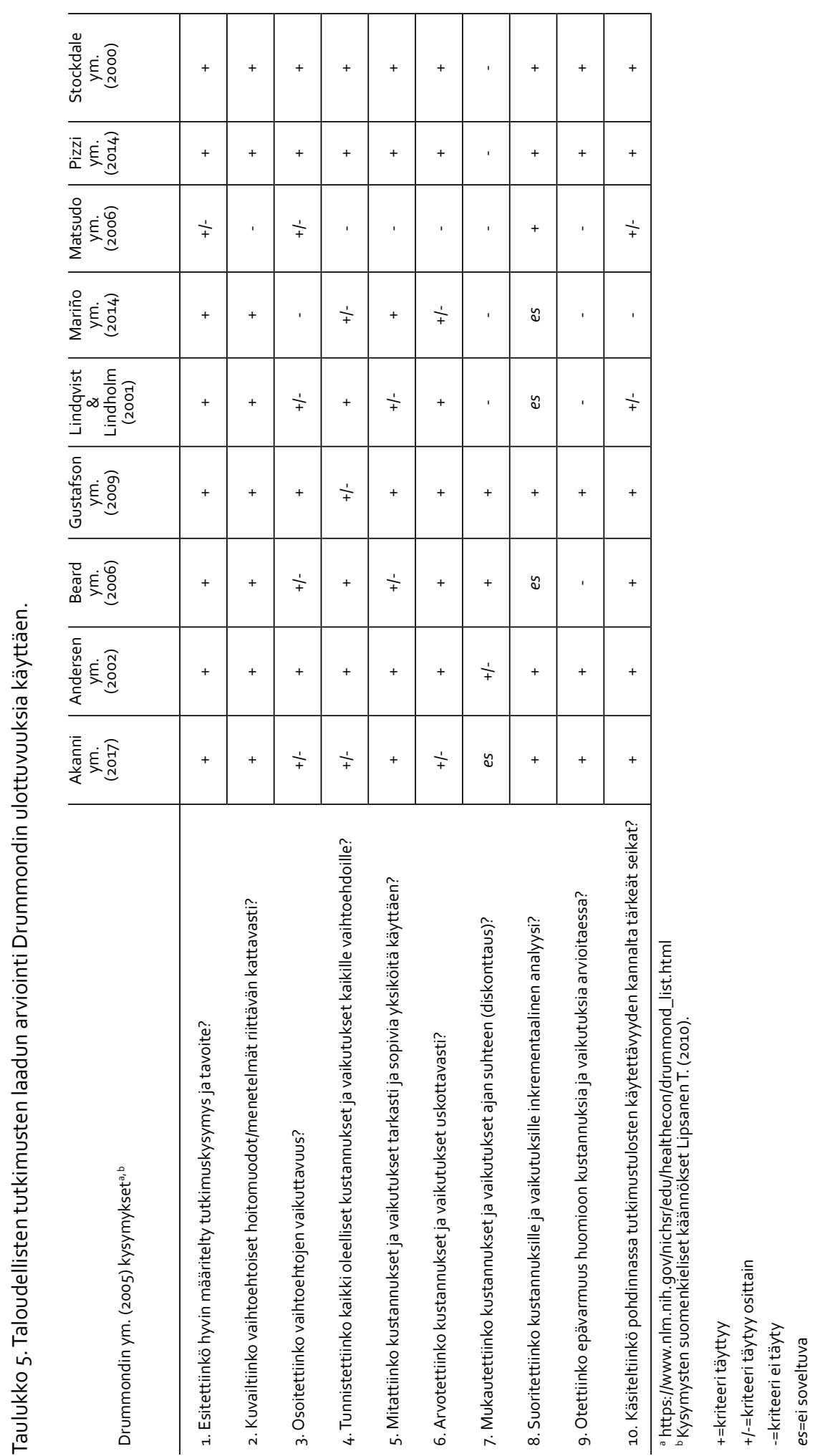


naltaehkäisyyn. Sosiaalista markkinointia hyödyntäviä interventioita pidettiin kaikissa tutkituissa artikkeleissa kustannus-vaikuttavina tai niiden myötä syntyvien säästöjen arvioitiin ylittävän kustannukset terveyden- ja hyvinvoinnin edistämisessä. Katsauksessa käsitellyt taloudelliset arviointitutkimukset eivät olleet kuitenkaan yhteismitallisia toisiinsa nähden, sillä taloudellisten analyysien päätöksentekosäännöt poikkesivat toisistaan. Tutkimusten erot liittyivät myös arviointitulosten erilaiseen tulkintaan, sillä joissakin maissa päätöksentekoa ohjaavat kustannus-vaikuttavuuden kynnysarvot on määritelty, mutta toisissa ei.

Useimmissa tutkimuksissa vaikuttavuutta arvioitiin mittareilla, joita ei ole käytetty laajasti ja joiden mittausominaisuudet tunnetaan huonosti. Tämä voi olla juuri kyseisen toiminnan arvioinnin kannalta tarkoituksenmukaista, mutta vaikuttavuuden mittaaminen vakiintuneilla menetelmillä osaltaan parantaisi tulosten hyödynnettävyyttä ja yleistettävyyttä (esim. Corrieri ym. 2011; Drewnowski ym. 2003; Konu ym. 2009; Sefton ym. 2004). Eroja tutkimusten välillä oli niin ikään myös tutkimusten asetelmissa, otoskoossa ja seurantamittausten ajoituksessa. Joistakin artikkeleista puuttui myös selvä kuvaus toimenpiteistä, joihin interventioita verrattiin. Sosiaaliset interventiot tavoittelevat usein kokonaisvaltaisia vaikutuksia, ja niiden kohteena voivat olla kokonaiset yhteisöt tai ryhmät. Tällöin saatetaan joutua tekemään esimerkiksi eettisistä ja käytännöllistä syistä myönnytyksiä tutkimuksissa käytettyihin koeasetelmiin (esim. Sefton ym. 2004). Tällaiset tekijät voivat vaikuttaa tutkimuksissa raportoituihin tuloksiin. Sosiaalisia interventioita arvioivan laadukkaan vaikuttavuus- ja kustannus-vaikuttavuustiedon tuottaminen on katsaukseen valikoituneiden arviointitutkimusten perusteella mahdollista, mutta haastavaa ja tuloksiin liittyy epävarmuutta. Kansalliset erot palvelujärjestelmissä, niiden rahoituksessa ja palveluiden saatavuudessa hankaloittavat myös osaltaan kansainvälisten tutkimusten tulosten vertailua suomalaiseen palvelujärjestelmään.
Samansuuntaisiin tuloksiin on tultu myös ennaltaehkäisevien perhepalveluiden taloudellisia tutkimuksia arvioineessa systemaattisessa katsauksessa (Paakkonen 2015).

Monet taloudelliset arvioinnit arvioivat interventioita, joiden tavoitteet liittyivät ikääntyneiden fyysisen aktiivisuuden lisäämiseen. Tällaiset hyvin suunnitellut toimet voivat olla arvioitujen tutkimusten perusteella tehokkaita terveydenedistämisessä. Kustannusten arvioinnin näkökulmasta vapaaehtoisuuteen ja vertaissuhteisiin perustuvien interventioiden arviointiin liittyy esimerkiksi kysymyksiä vapaaehtoistyön arvottamisesta. Katsauksessa käsitellyt laajemmista näkökulmista toteutetut arviointitutkimukset puolestaan viittaavat siihen, että kohdennetummat, sosiaalista markkinointia ja kohderyhmien osallistamista hyödyntävät palvelut voivat olla tehokkaita, ja että niiden lisääminen on periaatteessa mahdollista, mutta ei ilman lisäpanostusta.

\section{Tutkimuksen vahvuudet ja heikkoudet}

Tämän kartoittavan kirjallisuuskatsauksen tarkoituksena oli luoda riittävällä täsmällisyydellä mahdollisimman kattava käsitys ikääntyneille suunnattujen sosiaalisen markkinoinnin interventioiden aiemmasta taloudellisesta arviointitutkimuksesta sekä arvioida aiemman tutkimuksen laatua. Hakua ei tästä syystä rajattu tiukasti koskemaan vain tietyntyyppisiä interventioita, taloudellisen arvioinnin tyyppejä, maantieteellistä sijaintia, koeasetelmia tai tiettyä ajanjaksoa.

Sosiaalisen markkinoinnin operationalisoimiseksi tässä katsausartikkelissa käytettiin Andreasenin (2002) määritelmää, jonka avulla pyrittiin tunnistamaan sosiaalista markkinointia hyödyntävät interventiot käyttäytymisen muutokseen tähtäävien (psyko)sosiaalisten interventioiden laajemmasta joukosta. Tällainen menetelmä ei ole aukoton ja siinä jouduttiin tukeutumaan tietoon, jonka tutkijat julkaisussa kertoivat, ja hyödyntämään usein rajallisesti taustoittavia kuvauksia tai suunni- 
telmia. Onkin mahdollista, että osa käsitellyistä interventioista on katsauksessa luokiteltu sosiaaliseksi markkinoinniksi, vaikka ne voitaisiin määritellä myös toisin yhteisöllisten työmenetelmien ja toimintatapojen joukossa. Toisaalta tutkimusten itseidentifioituminen sosiaaliseksi markkinoinniksi ei ole osoittautunut aina takeeksi siitä, että sosiaalisen markkinoinnin periaatteita toteutettaisiin niissä tästä huolimatta kovin hyvin (esim. Stead ym. 2007). Kaikissa taloudellisissa arviointitutkimuksissa interventioita pidettiin kustannus-vaikuttavina tai niiden säästöjen arvioitiin ylittävän kustannukset terveyden- ja hyvinvoinnin edistämisessä. Tuloksiin voi liittyä myös julkaisuharhaa. Toisin sanoen, päinvastaisia tuloksia on saatettu jättää julkaisematta.

\section{Johtopäätökset}

Tässä kirjallisuuskatsauksessa tutkittiin ikääntyneille suunnatun sosiaalisen markkinoinnin taloudellisia arviointitutkimuksia. Tiedossamme ei ole aiempaa katsaustutkimusta, jossa yhdistyisivät sosiaalisen markkinoinnin, ikääntyneiden hyvinvoinnin ja terveyden edistämisen ja taloudellisen arvioinnin näkökulmat. Tutkituissa interventioissa tavoiteltiin terveyden edistämistä ja sairauksien ennaltaehkäisyä ja niiden kohteena olivat usein vähemmistö- ryhmiin kuuluvat ikääntyneet. Tällaisten interventioiden taloudellista arviointia on tehty vähän ja arviointien taso on katsauksen tulosten perusteella vaihteleva.

Tutkimukset poikkesivat toisistaan analyysityypeiltään, arviointiasetelmiltaan, arviointinäkökulmiltaan ja hyötyvaikutusten mittaustavoiltaan. Tällaiset tekijät vaikeuttavat tutkimusten tulosten tulkintaa. Katsauksen tutkimusten tulokset viittaavat kuitenkin siihen, että hyvin suunnitellut, osallistavat, kansalaislähtöiset toimet voivat olla vaikuttavia ja potentiaalisesti myös taloudellisessa mielessä tehokkaita keinoja ikääntyneiden terveyden ja hyvinvoinnin edistämisessä. Tuloksia tulkittaessa tulee huomioida myös palvelujärjestelmien erot, jotka voivat suoraan näkyä esimerkiksi palvelujen saatavuudessa. Sosiaalista markkinointia hyödyntävien, osallistavien interventioiden tehokkuutta on syytä tutkia yhteiskunnallisesti heikossa asemassa olevien ryhmien terveyden ja hyvinvoinnin edistämisessä suomalaisen sosiaali- ja terveyspalvelujärjestelmän erityispiirteet tunnistavalla tavalla.

\section{Yhteydenotto:}

Jussi Partanen, YTM, Yhteiskuntatieteiden tiedekunta (terveystieteet), Tampereen yliopisto Sähköposti: jussi.partanen@staff.uta.fi/

Partanen.Jussi.T@student.uta.fi

Andersen, M. R., Hager, M., Su, C., \& Urban, N. (2002). Analysis of the cost-effectiveness of mammography promotion by volunteers in rural communities. Health Education E Behavior, 29(6), 755-770. doi:10.1177/109019802237942

Andreasen, A. R. (2002). Marketing social marketing in the social change marketplace. Journal of Public Policy \& Marketing, 21(1), 3-13.

Arksey, H., \& O’Malley, L. (2005). Scoping studies: Towards a methodological framework. International Journal of Social Research Methodology, 8(1), 19-32. 
Beard, J., Rowell, D., Scott, D., van Beurden, E., Barnett, L., Hughes, K., \& Newman, B. (2006). Economic analysis of a community-based falls prevention program. Public Health, 120(8), 742-751. doi:10.1016/j.puhe.2006.04.011

Bertram, M. Y., Lauer,J. A., De Joncheere, K., Edejer, T., Hutubessy, R., Kieny, M. et al. (2016). Costeffectiveness thresholds: Pros and cons. Bulletin of the World Health Organization, 94(12), 925-930.

Byford, S., \& Sefton, T. (2003). Economic evaluation of complex health and social care interventions. National Institute Economic Review, 186(1), 98-108.

Carins, J. E. \& Rundle-Thiele, S. R. (2014). Eating for the better: a social marketing review (20002012). Public Health Nutr., 17(7), 1628-1639. doi:10.1017/S1368980013001365 [doi].

Christensen, K., Doblhammer, G., Rau, R., \& Vaupel, J. W. (2009). Ageing populations: The challenges ahead. Lancet, 374(9696), 1196-1208. doi:10.1016/S0140-6736(09)61460-4

Christopoulos, A., \& Reynolds, L. (2009). Evaluating social marketing: lessons from ShowCase. Perspectives in Public Health, 129(6), 272-276. doi:10.1177/1757913909347668

Corrieri, S., Heider, D., Riedel-Heller, S. G., Matschinger, H., \& König, H. (2011). Cost-effectiveness of fall prevention programs based on home visits for seniors aged over 65 years: a systematic review. International Psychogeriatrics, 23(5), 711723. doi:10.1017/S1041610210002280

Derose, K., Fox, S., Reigadas, E., \& Hawes-Dawson, J. (2000). Church-based telephone mammography counseling with peer counselors. Journal of Health Communication, 5(2), 175-188. doi:10.1080/108107300406884

Drewnowski, A., Monsen, E., Birkett, D., Gunther, S., Vendeland, S., Su, J., \& Marshall, G. (2003). Health screening and health promotion programs for the elderly. Disease Management \& Health Outcomes, 11(5), 299-309. doi:10.2165/00115677-200311050-00003

Drummond, M. F. (2005). Methods for the economic evaluation of health care programmes. Oxford: $\mathrm{Ox}^{-}$ ford University Press.

Edwards, R. D. (2012). Population aging, the dependency burden, and challenges facing preventive medicine. Preventive Medicine, 55(6), 533-534.

French, J., \& Blair-Stevens, C. (2007). Big pocket guide to social marketing. National Social Marketing Centre.
French, J. (2011). Social marketing and public health: Theory and practice. New York: Oxford University Press.

French, J., \& Russell-Bennett, R. (2015). A hierarchical model of social marketing. Journal of Social Marketing, 5(2), 139-159.

Fujihira, H., Kubacki, K., Ronto, R., Pang, B., \& Rundle-Thiele, S. (2015). Social marketing physical activity interventions among adults 60 years and older. Social Marketing Quarterly, 21(4), 214229. doi:10.1177/1524500415606671

Gitlin, L. N., Harris, L. F., McCoy, M., Chernett, N. L., Jutkowitz, E., \& Pizzi, L. T. (2012). A community-integrated home based depression intervention for older African Americans: descripton of the beat the blues randomized trial and intervention costs. BMC Geriatrics, 12(1), 4. doi:10.1186/14712318124

Gordon, R. (2013). Unlocking the potential of upstream social marketing. European Journal of Marketing, 47(9), 1525-1547.

Gustafson, A., Khavjou, O., Stearns, S. C., Keyserling, T. C., Gizlice, Z., Lindsley, S., S., Bramble, K., Garcia, B., Johnston, L., Will, J., Poindexter, P., Ammerman, A. S. \& Samuel-Hodge, C. D. (2009). Cost-effectiveness of a behavioral weight loss intervention for low-income women: the Weight-wise program. Preventive Medicine, 49(5), 390-395. doi://dx.doi.org/10.1016/j. ypmed.2009.09.007

Israel, B. A., Schulz, A. J., Parker, E. A., \& Becker, A. B. (1998). Review of community-based research: assessing partnership approaches to improve public health. Annual Review of Public Health, 19(1), 173-202. doi:10.1146/annurev. publhealth.19.1.173

Kempton, A. (2000). Older people can stay on their feet: final results of a community-based falls prevention programme. Health Promotion International, 15(1), 27-33. doi:10.1093/heapro/15.1.27

Konu, A., Rissanen, P., Ihantola, M., \& Sund, R. (2009). "Vaikuttavuus" suomalaisissa terveydenhuollon tutkimuksissa. Sosiaalilääketieteellinen Aikakauslehti, (46), 285-297.

Kotler, P., \& Zaltman, G. (1971). Social Marketing: an approach to planned social change. Journal of Marketing, 35(3), 3-12. doi:10.2307/1249783

Kubacki, K., Sharyn Rundle-Thiele, Lahtinen, V. \& Parkinson, J. (2015). A systematic review assessing the extent of social marketing principle use 
in interventions targeting children (2000-2014).

Young Consumers, 16(2), 141-158.

doi:10.1108/YC-08-2014-00466.

Levac, D., Colquhoun, H., \& O’Brien, K. K. (2010).

Scoping studies: advancing the methodology. Implementation Science, 5(1), 69.

doi:10.1186/1748-5908-5-69

Lindqvist, K., \& Lindholm, L. (2001). A cost-benefit analysis of the community-based injury prevention programme in Motala, Sweden: a WHO Safe Community. Public Health, 115(5), 317-322. doi://dx.doi.org/10.1038/sj.ph.1900793

Lipsanen, T. (2010) Lääkehoidon kokonaisarvioinnin kustannusvaikuttavuus: järjestelmällinen kirjallisuuskatsaus. Pro Gradu -tutkielma. Helsingin yliopisto, Farmasian tiedekunta.

Mariño, R. J., Fajardo, J., Calache, H., \& Morgan, M. (2014). Cost-minimization analysis of a tailored oral health intervention designed for immigrant older adults. Geriatrics \& Gerontology International, 14(2), 336-340. doi:10.1111/ggi.12103

Mariño, R.J., Calache, H., Wright, C., Schofield, M., \& Minichiello, V. (2004). Oral health promotion programme for older migrant adults. Gerodontology, 21(4), 216-225.

doi:10.1111/j.1741-2358.2004.00035.x

Matsudo S. M., Matsudo V. R., Andrade D. R., Araújo T. L., Andrade E., de Oliveira L., \& Braggion G. (2004). Physical activity promotion: experiences and evaluation of the Agita São Paulo program using the ecological mobile model. Journal of Physical Activity and Health, (1), 81-97.

Matsudo, S. M., Matsudo, V. R., Andrade, D. R., Araújo, T. L., \& Pratt, M. (2006). Evaluation of a physical activity promotion program: The example of Agita São Paulo. Evaluation and Program Planning. Volume 29, (3), 301-311. doi://doi.org/10.1016/j.evalprogplan.2005. 12.006

McClure, R. J., Hughes, K., Ren, C., McKenzie, K., Dietrich, U., Vardon, P., Davis, E. \& Newman, B. (2010), The population approach to falls injury prevention in older people: findings of a two community trial. BMC Public Health, 10(1), 79. doi:10.1186/1471-2458-10-79

Mooney, G. H. (2003). Economics, medicine and health care. Pearson Education Limited.

Mui, A. C., Glajchen, M., Chen, H., \& Sun, J. (2012). Developing an older adult volunteer program in a New York Chinese community: an evi- dence-based approach. Ageing International, 38(2), 108-121.

doi:10.1007/s12126-012-9160-5

Ory, M. G., Smith, M. L., Howell, D., Zollinger, A., Quinn, C., Swierc, S. M., \& Stevens, A. B. (2014). The Conversion of a practice-based lifestyle enhancement program into a formalized, testable program: from Texercise classic to Texercise select. Frontiers in Public Health, 2, 291. doi:10.3389/fpubh.2014.00291

Paakkonen, T. (2015). Ehkäisevän työn kustannusvaikuttavuus lapsiperhepalveluissa: systemaattinen kirjallisuuskatsaus. Työpaperi 12/2015. Terveyden ja hyvinvoinnin laitos.

Palmer, S. \& Raftery, J. (1999). Opportunity cost. BMJ: British Medical Journal, 318(7197), 15511552.

Pizzi, L. T., Jutkowitz, E., Frick, K. D., Suh, D., Prioli, K. M., \& Gitlin, L. N. (2014). Cost-effectiveness of a community-integrated home-based depression intervention in older African Americans. Journal of the American Geriatrics Society, 62(12), 2288-2295. doi:10.1111/jgs.13146

Read, S., Grundy, E., \& Foverskov, E. (2015). Socio-economic position and subjective health and well-being among older people in Europe: a systematic narrative review. Aging \& Mental Health, 20(5), 529-542.

doi:10.1080/13607863.2015.1023766

Samuel-Hodge, C. D., Johnston, L. F., Gizlice, Z., Garcia, B. A., Lindsley, S. C., Bramble, K. P., Hardy, T. E., Ammerman, A. S., Poindexter, P.A., Will, J. C. \& Keyserling, T. C. (2009), Randomized trial of a behavioral weight loss intervention for low-income women: The Weight Wise Program, Obesity, 17, (10),1891-1899.

doi:10.1038/oby.2009.128

Sefton, T., Byford, S., McDaid, D., \& Knapp, M. (2004). Taloudellinen arviointi sosiaalialalla. STAKES. Sosiaali- ja terveysalan tutkimus- ja kehittämiskeskus.

Sintonen, H., Pekurinen, M. (2006). Terveystaloustiede. Helsinki: WSOY.

Stead, M., Gordon, R., Angus, K., \& McDermott, L. (2007). A systematic review of social marketing effectiveness. Health Education, 107(2), 126-191. doi:10.1108/09654280710731548

Stephens, C. (2007). Community as practice: social representations of community and their implications for health promotion. Journal of Commu- 
nity \& Applied Social Psychology, 17(2), 103-114. doi:10.1002/casp.884

Stockdale, S. E., Keeler, E., Duan, N., Derose, K. P., $\&$ Fox, S. A. (2000). Costs and cost-effectiveness of a church-based intervention to promote mammography screening. Health Services Research, 35(5), 1037-1057.

Szmigin, I., Bengry-Howell, A., Griffin, C., Hackley, C., \& Mistral, W. (2011). Social marketing, individual responsibility and the "culture of intoxication". European Journal of Marketing, 45(5), 759-779. doi:10.1108/03090561111120028

Truong, V.D. (2014). Social Marketing: A systematic review of research 1998-2012. Social Marketing Quarterly, 20(1), 15-34. doi:10.1177/1524500413517666

Truong, V. D., \& Hall, C. M. (2013). Social marketing and tourism. Social Marketing Quarterly, 19(2), 110-135. doi:10.1177/1524500413484452

Turunen, P. (2009) Nordic community work in transition: a change toward diversity and reflexivity. Teoksessa Hutchinson, G. S. (toim.), Community Work in the Nordic Countries - New Trends (s. 38-63). Oslo: Universitetsforlag..
Wallerstein, N. B., \& Duran, B. (2006). Using community-based participatory research to address health disparities. Health Promotion Practice, 7(3), 312-323. doi:10.1177/1524839906289376

Wang, J., Chen, C., Lai, L., Chen, M., \& Chen, M. (2014). The effectiveness of a community-based health promotion program for rural elders: A quasi-experimental design. Applied Nursing Research, 27(3), 181-185. doi://doi.org/10.1016/j.apnr.2013.11.014

Will, J. C., Farris, R. P., Sanders, C. G., Stockmyer, C. K., \& Finkelstein, E. A. (2004). Health promotion interventions for disadvantaged women: overview of the WISEWOMAN projects. Journal of Women's Health (2002), 13(5), 484-502. doi:10.1089/1540999041281025

Zanjani, F., Kruger, T., \& Murray, D. (2012). Evaluation of the mental healthiness aging initiative: Community program to promote awareness about mental health and aging issues. Community Mental Health Journal, 48(2), 193-201. doi:10.1007/s10597-011-9373-1 